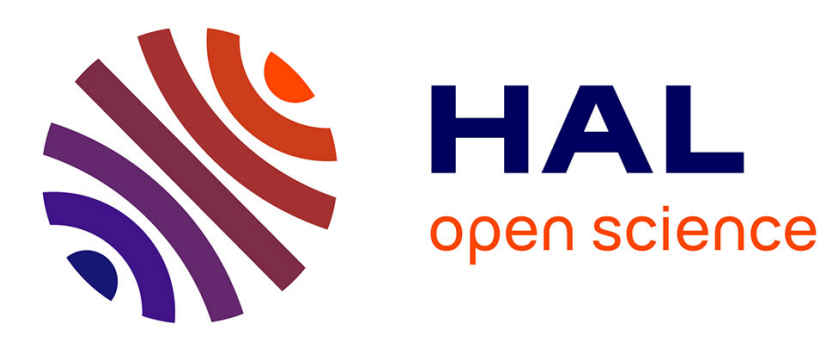

\title{
Developing a Theoretical Model to Examine Consumer Acceptance Behavior of Mobile Shopping
}

Hannah R. Marriott, Michael D. Williams

\section{To cite this version:}

Hannah R. Marriott, Michael D. Williams. Developing a Theoretical Model to Examine Consumer Acceptance Behavior of Mobile Shopping. 15th Conference on e-Business, e-Services and e-Society (I3E), Sep 2016, Swansea, United Kingdom. pp.261-266, 10.1007/978-3-319-45234-0_24 . hal-01702141

\section{HAL Id: hal-01702141 \\ https://hal.inria.fr/hal-01702141}

Submitted on 6 Feb 2018

HAL is a multi-disciplinary open access archive for the deposit and dissemination of scientific research documents, whether they are published or not. The documents may come from teaching and research institutions in France or abroad, or from public or private research centers.
L'archive ouverte pluridisciplinaire HAL, est destinée au dépôt et à la diffusion de documents scientifiques de niveau recherche, publiés ou non, émanant des établissements d'enseignement et de recherche français ou étrangers, des laboratoires publics ou privés. 


\title{
Developing a theoretical model to examine consumer acceptance behavior of mobile shopping
}

\author{
Hannah R. Marriott ${ }^{1, *}$ and Michael D. Williams ${ }^{1}$ \\ ${ }^{1}$ School of Management, Swansea University, Swansea, UK \\ \{632527, m.d.williams\}@ swansea.ac.uk
}

\begin{abstract}
Mobile activity is increasing in popularity with Smartphones and Tablets being used for a variety of daily online activities. However, the number of mobile users utilizing mobile devices for the purpose of shopping is relatively low and there has been limited theoretical research examining the acceptance behavior of consumers in the UK. This research aims to develop a theoretically grounded adoption model to examine UK consumers' mobile shopping acceptance behavior. Through consideration into findings from existing research, a theoretically grounded model is developed by extending UTAUT2 with perceived risk, trust, mobile affinity and innovativeness. This theoretical model can subsequently be empirically tested with data gathered from the UK.
\end{abstract}

Keywords: Acceptance, consumer behavior, mobile shopping (m-shopping), Perceived risk, UK, UTAUT2

\section{Introduction}

Smartphones and Tablets ('mobile devices') are considered a new generation of operating system allowing for an array of computer-like functions whilst providing consumers with higher levels of convenience than previously experienced with computers $[1,2]$. Mobile devices have become heavily integrated into the lives of modern day users and are used for a variety of daily activities, including conducting in mobile banking (m-banking), mobile learning (m-learning), mobile payments (m-payments) and mobile shopping (m-shopping). M-shopping comprises of the online searching, browsing, comparing and purchasing of goods and services through wireless mobile devices $[3,4,5]$. This research examines m-shopping at the consumer level, with primary consideration into business-to-consumer relationships.

Increased functionality in mobile devices has seen the growth of Internet sales, with mobile orders expected to increase at $21-29 \%$ by the end of 2016 [6]. Although $\mathrm{m}$-shopping activity is increasing, it remains the least preferable and least trusted means of online shopping worldwide [2]. Risk perceptions subsequently limit the number of consumers adopting m-shopping activities and practitioners have stressed the significance of developing effective marketing techniques and mobile systems to increase adoption willingness [7]. However, there is limited empirical research examining $\mathrm{m}$-shopping acceptance behavior of UK consumers, restricting 
validity of findings to geographical contexts. Insight into UK consumers will further validate the significance of various theoretical acceptance factors and provide a more geographically holistic understanding into m-shopping acceptance behavior.

This paper provides an overview of theories and models used in mobilerelated research, establishing those most commonly used and those most underutilized, for the purpose of identifying an appropriate research model for m-shopping acceptance behavior in the UK that can be tested using empirical data. The conceptual model incorporates acceptance factors and barriers towards $\mathrm{m}$-shopping in a contemporary light. The remainder of this paper is as follows. First, in reviewing acceptance literature surrounding $\mathrm{m}$-commerce, $\mathrm{m}$-banking, $\mathrm{m}$-payment and $\mathrm{m}$-shopping literature, the most commonly used Information Systems (IS) theoretical adoption models to date will be highlighted. Second, exploration into the most appropriate adoption model will be discussed, followed by its proposed extensions. The paper concludes with an overview of findings and discussion into areas for further empirical work.

\section{Overview of theories and model in mobile-related research}

Technology acceptance research has utilized a variety of theoretical models to explain consumer behaviors across various areas in the digital environment. In the digital retail environment, comprising of electronic commerce (e-commerce) and mobile commerce (m-commerce), the most commonly adopted theoretical models have been the Theory of Reasoned Action (TRA) [8], Theory of Planned Behavior (TPB) [9], Technology Acceptance Model (TAM) [10], Unified Theory of Acceptance and Use of Technology (UTAUT) [11, 12] and the Diffusion of Innovation Theory (DOI) [13].

A review of the literature, conducted through keyword searches via Google Scholar and EbscoHost, revealed 26 quantitative studies relating to consumer mshopping behavior between 2002 and 2016. Of these studies, one adopts TPB, six adopt TAM, with two utilizing UTAUT; 17 studies fail to adopt a defined theoretical research model but re-affirm some significant variables of existing models. Due to limitations in m-shopping literature, it is appropriate to consider literature surrounding other sub-categories of $\mathrm{m}$-commerce to further develop an appropriate conceptual model. Therefore, research relating to $\mathrm{m}$-commerce, $\mathrm{m}$-services, $\mathrm{m}$-Internet and $\mathrm{m}$ payments will also be considered. The analysis of the subsequent 77 quantitative studies reveals TAM as the most commonly used IS adoption model, with 44.1 percent of studies utilizing it. The number of studies not adopting a grounded theoretical model accounts for 29.8 percent of these studies, leaving a small percent of studies adopting DOI, TPB, TRA and UTAUT.

As the most commonly used research model, TAM has been empirically extended to incorporate trust, innovativeness and affinity. Aldás-Manzano et al. [14] extended TAM to include personality variables of innovativeness and mobile affinity and found that the variance of $\mathrm{m}$-shopping intention is eight percent higher when the two personality variables are added to TAM. Although not extended to TAM, Bigné et al. [15] provides support for the inclusion of mobile affinity as their study explained over 60 percent variance on intention when included in their model. 
TAM is also the most regularly utilized model when examining perceived risk ('risk') and trust. Zhang [16] observes trust as having 85.7 percent and risk as having 87.5 percent significance on behavioral intention. Furthermore, Nassoura [17] considers trust to be a significant positive predictor of m-commerce adoption. UTAUT has increased in popularity in more recent years and has been used to further explain trust. UTAUT has been most regularly extended with trust within m-banking research; Foon and Fah [18] found trust to be a significant predictor of behavioral intention and that the extended model explains 56.5 percent of variance. Furthermore, Chong [3] observed trust to have a significant positive relationship with behavioral intention towards $\mathrm{m}$-commerce in China and accounts for 33.4 percent of variance.

\section{Selection of theoretical model}

The TRA, being a development of the Information Integration Theory (IIT), collaboratively examines consumer beliefs and evaluations on their attitudes and normative beliefs to predict their behavioral intention and actual behavior [8, 19]. Although TRA has made fundamental advances in consumer behavior research, it has been criticized regarding its lack of consideration into behavioral control; TRA has subsequently been replaced by TPB, which examines the effects of attitude, subjective norms and perceived behavioral control on behavioral intention, and increased variance from 32.7 percent, in TRA, to 44.05 percent. Although the significance of incorporating perceived behavioral control is maintained in e-commerce literature, its application to intention-related research is limited $[20,11]$.

Due to limitations in TPB, TAM is considered the most widely adopted theoretical models in IS adoption research as it is considered a better predictor of overall intention than TRA and TPB [21, 19]. TAM incorporates perceived usefulness (PU) and perceived ease of use (PEOU) on behavioral intention. Due to its minimalistic nature, researchers have drawn attention to it as having reached saturation point. After its establishment in 2003, UTAUT offered a more explanatory theoretical model through the incorporation of performance expectancy, derived from PU, effort expectancy, derived from PEOU, social influence and facilitating conditions, alongside the moderating effects of age, gender, experience and voluntariness of use [11].

Although UTAUT is a widely accepted IS adoption model, the high numbers of its citation are considered not to be truly representative of its actual utilization as a theoretical research model [22]. Furthermore, its application to m-shopping research has been minimal. Nevertheless, UTAUT was designed to explain and predict employee technology acceptance within organizations, rather than in a consumer context. In response to its limitations, Venkatesh et al. [12] proposed an extension of this model to accommodate the consumer context, giving rise to UTAUT2. UTAUT2 incorporates the original UTAUT constructs of performance expectancy, effort expectancy, social influence and facilitating conditions and incorporates hedonic motivation, price value and habit. Furthermore, due to the removal of the employment context, voluntariness of use is not included in UTAUT2 as it is presumed that consumers adopt technologies voluntarily, leaving gender, age and experience as moderators. 
Since its establishment in 2012, UTAUT2 has been considered a substantial improvement in explaining consumer behavioral intention and has since been used in m-payments, m-internet and m-banking research. UTAUT2 has increased the explained variance of behavioral intention from 56 percent to 74 percent and of use behavior from 40 percent to 52 percent [12]. Despite significant developments of UTAUT2, it remains significantly underutilized in m-shopping research. Furthermore, although UTAUT2 was originally developed with consideration into American consumers, it has been recommended for its use to stretch across geographical contexts [12]. Consequently, applying UTAUT2 to an m-shopping acceptance context within the ambit of the UK provides both theoretical and practical contributions.

\section{$4 \quad$ Proposed extensions of UTAUT2}

Across the mobile research environment, theorists have seldom applied theoretical models without also extending them. Venkatesh et al. [12] stressed the importance of further research extending UTAUT2 for the purpose of finding other key acceptance factors across different research contexts. It is therefore appropriate for both the application and extension of UTAUT2 examine UK consumer m-shopping acceptance behavior. Through analysis into $\mathrm{m}$-shopping and $\mathrm{m}$-commerce literature, it can be proposed that UTAUT2 be extended to incorporate mobile affinity, personal innovativeness, multi-dimensional risk and multi-dimensional trust.

Mobile affinity is the personal closeness with a user's mobile devices and examination into its various situational contexts is significant in mobile related research $[2,23]$. Although UTAUT2 is better suited to consumer related contexts, it does not directly relate to $\mathrm{m}$-shopping situations. In incorporating mobile affinity into UTAUT2, UK m-shopping acceptance behavior can be further explained.

Innovativeness is the willingness of individuals to try something new in relation to their experience [13]. Although it is suggested that innovativeness is incorporated with hedonic motivation, within UTAUT2 [12], innovativeness relates more to an individual's predisposition to adopt technology rather than towards their perceived enjoyment of that technology. Innovativeness will subsequently be considered in this research as it has previously been considered one of the most significant predictors of behavioral intention [14].

Risk is a multidimensional construct, comprising of financial, psychological, physical, social, time and performance risks, providing feelings of anxiety and uncertainty, reducing the likelihood of consumers adopting technologies [24]. Although risk has been regularly implemented into existing models, it is seldom considered multi-dimensionally and has not been examined in relation to $\mathrm{m}$-shopping acceptance. Due to the various types of risk, it is appropriate to examine risk as a multidimensional construct in this research as a negative determinant of behavioral intention.

Trust is the belief that one party will fulfil their obligations, which is also of a multidimensional nature. There are many origins of trust throughout the $\mathrm{m}$-shopping process, including trust in the $\mathrm{m}$-vendor, the $\mathrm{m}$-shopping platform and the mobile device itself. Although trust is often considered a unitary concept, this research aims 
to extend UTAUT2 to incorporate various dimensions of trust and to examine its direct effect on behavioral intention and its effect on risk reduction.

\section{Conclusion}

Despite the increase of m-shopping acceptance literature across a variety of geographical contexts, examination into UK consumer's behavior towards m-shopping has remained in its infancy. This research has developed a theoretical consumer adoption model to examine and help predict consumer acceptance of m-shopping in the context of the UK. Due to the increasing utilization of UTAUT2 in consumer research, it has been applied to this research and extended to include perceived risk, trust, mobile affinity and innovativeness. To further validate these theoretical extensions to UTAUT2, this research requires empirical investigation. Furthermore, future research in this area can further examine UTAUT2 alongside other acceptance variables to further contribute to m-shopping knowledge.

\section{References}

1. Büllinger, F., \& Stamm, P. (2012). Mobile Commerce via Smartphone \& Co: Analyse und Prognose des zukünftigen Marktes aus Nutzerperspektive. Hg. v. Verbraucherzentrale Bundesverband $\mathrm{eV}$. Wissenschaftliches Institut für Infrastruktur und Kommunikationsdienste GmbH. Büyüközkan, G. (2009). Determining the mobile commerce user requirements using an analytic approach. Computer Standards \& Interfaces, 31(1), 144-152.

2. Holmes, A., Byrne, A., \& Rowley, J. (2014). Mobile shopping behaviour: insights into attitudes, shopping process involvement and location. International Journal of Retail \& Distribution Management, 42(1), 25-39.

3. Chong, A. Y. L. (2013b). Predicting m-commerce adoption determinants: A neural network approach. Expert Systems with Applications, 40(2), 523-530.

4. Groß, M. (2014). Exploring the acceptance of technology for mobile shopping: an empirical investigation among Smartphone users. The International Review of Retail, Distribution and Consumer Research, (ahead-of-print), 1-21.

5. Yang, K., \& Kim, H. Y. (2012). Mobile shopping motivation: an application of multiple discriminant analysis. International Journal of Retail \& Distribution Management, 40(10), 778-789.

6. Mulpuru, S., Johnsob, C., Wu, S., Roberge, D., \& Naparstek, L. (2014). 'US Mobile Retail Forecast, 2012 to 2017'. Forrester Research. Retrieved from https://www.forrester.com/US+Mobile+Phone+And+Tablet+Commerce+Forecas t+2013+To+2018/fulltext/-/E-res115514\#AST971255

7. Hung, M. C., Yang, S. T., \& Hsieh, T. C. (2012). An examination of the determinants of mobile shopping continuance. International Journal of Electronic Business Management, 10(1), 29.

8. Fishbein, M., \& Ajzen, I. (1975). Belief, attitude, intention and behavior: An introduction to theory and research. 
9. Ajzen, I. (1991). The theory of planned behavior. Organizational behavior and human decision processes, 50(2), 179-211.

10. Davis, F. D. (1989). Perceived usefulness, perceived ease of use, and user acceptance of information technology. MIS quarterly, 319-340.

11. Venkatesh, V., Morris, M. G., Davis, G. B., \& Davis, F. D. (2003). User acceptance of information technology: Toward a unified view. MIS quarterly, 425478.

12. Venkatesh, V., Thong, J. Y., \& Xu, X. (2012). Consumer acceptance and use of information technology: extending the unified theory of acceptance and use of technology. MIS quarterly, 36(1), 157-178.

13. Rogers, E. (1995). Diffusion of Innovations (4th ed.), New York: Free Press

14. Aldás-Manzano, J., Ruiz-Mafe, C., \& Sanz-Blas, S. (2009). Exploring individual personality factors as drivers of M-shopping acceptance. Industrial Management \& Data Systems, 109(6), 739-757.

15. Bigné, E., Ruiz-Mafé, C., \& Sanz-Balz, S. (2007). Key Drivers of Mobile Commerce Adoption. An Exploratory Study of Spanish Mobile Users. JTAER, 2(2), 48-60.

16. Zhang, L., Zhu, J., \& Liu, Q. (2012). A meta-analysis of mobile commerce adoption and the moderating effect of culture. Computers in Human Behavior, 28(5), 1902-1911.

17. Nassuora, A. B. (2013). Understanding factors affecting the adoption of $\mathrm{m}$ commerce by consumers. Journal of Applied Sciences, 13(6), 913.

18. Foon, Y. S., \& Fah, B. C. Y. (2011). Internet banking adoption in Kuala Lumpur: an application of UTAUT model. International Journal of Business and Management, 6(4), 161.

19. Wong, C. H., Lee, H. S., Lim, Y. H., Chua, B. H., \& Tan, G. W. H. (2012). Predicting the consumers' intention to adopt mobile shopping: an emerging market perspective. International Journal of Network and Mobile Technologies, 3(3), 2439.

20. Grandón, E. E., Nasco, S. A., \& Mykytyn, P. P. (2011). Comparing theories to explain e-commerce adoption. Journal of Business Research, 64(3), 292-298.

21. Mathieson, K. (1991). Predicting user intentions: comparing the technology acceptance model with the theory of planned behavior. Information systems research, 2(3), 173-191.

22. Williams, M. D., Rana, N. P., Dwivedi, Y. K., \& Lal, B. (2011, June). Is UTAUT really used or just cited for the sake of it? a systematic review of citations of UTAUT's originating article. In ECIS.

23. Matthews, T., Pierce, J., \& Tang, J. (2009). No smart phone is an island: The impact of places, situations, and other devices on smart phone use. IBM RJ10452.

24. Jacoby, J., \& Kaplan, L. B. (1972). The components of perceived risk. Advances in consumer research, 3(3), 382-383. 